\title{
New And Interesting Orchid Records for Tanzania
}

Author(s): Benny Bytebier, Jane Sakwa, Hubert Kurzweil

Source: Journal of East African Natural History, 93(1):63-67. 2004.

Published By: Nature Kenya/East African Natural History Society

DOI: http://dx.doi.org/10.2982/0012-8317(2004)93[63:NAIORF]2.0.CO;2

URL: http://www.bioone.org/doi/full/10.2982/0012-8317\%282004\%2993\%5B63\%3ANAIORF

\%5D2.0.CO\%3B2

BioOne (www.bioone.org) is a nonprofit, online aggregation of core research in the biological, ecological, and environmental sciences. BioOne provides a sustainable online platform for over 170 journals and books published by nonprofit societies, associations, museums, institutions, and presses.

Your use of this PDF, the BioOne Web site, and all posted and associated content indicates your acceptance of BioOne's Terms of Use, available at www.bioone.org/page/terms_of_use.

Usage of BioOne content is strictly limited to personal, educational, and non-commercial use. Commercial inquiries or rights and permissions requests should be directed to the individual publisher as copyright holder. 


\title{
NEW AND INTERESTING ORCHID RECORDS FOR TANZANIA
}

\author{
Benny Bytebier \\ Biochemistry Department, Stellenbosch University \\ 7602 Stellenbosch, South Africa \\ bytebier@sun.ac.za \\ Jane Sakwa \\ Evolutionary Genomics Group, Botany and Zoology Department, \\ Stellenbosch University, 7602 Stellenbosch, South Africa \\ jsakwa@sun.ac.za \\ Hubert Kurzweil \\ Compton Herbarium, South African National Biodiversity Institute \\ 7735 Claremont, South Africa \\ kurzweil@nbi.ac.za
}

\begin{abstract}
The orchid taxa Brachycorythis ovata subsp. schweinfurthii, Habenaria arianae and Habenaria disparilis are newly recorded for Tanzania, while Brachycorythis congoensis is newly recorded for the floral region T7. A stable, pure yellow mutant of Disa erubescens is recorded for the first time.
\end{abstract}

\section{INTRODUCTION}

The Southern Highlands of Tanzania have long been recognised as an area of outstanding botanical richness and importance (Cribb \& Leedal, 1982; Lovett et al., 1994; Davenport \& Bytebier, 2004). In Africa, its terrestrial orchid diversity is only rivaled by the Western Cape and Drakensberg mountains in South Africa (Linder \& Kurzweil, 1999) and the Nyika Plateau in Malawi and Zambia (la Croix et al., 1991). For instance, out of 27 Disa species occurring in East Africa (Kenya, Uganda, Tanzania), 24 occur in the Southern Highlands (Summerhayes, 1968). Out of these 24 species, only 4 also occur in South Africa. This is why the first author chose this area to collect Disa taxa restricted to East and Central Africa for his molecular phylogenetic analysis of the genus. During his collecting trip a number of interesting and new orchid records were made, on which we report here.

\section{MATERIAL AND METHODS}

Currently known distribution was extracted from World Checklist of Monocots (2004) and checked against relevant floristic treatment such as Flora of Tropical East Africa (Summerhayes, 1968), Flore d'Afrique Central (Geerinck, 1984), Flora of Ethiopia and 
Eritrea (Cribb \& Thomas, 1997), Flora Zambesiaca (la Croix \& Cribb, 1995) and Orchids of Malawi (la Croix et al., 1991). Distribution abbreviations follow Hollis \& Brummitt (1992). Specimens are deposited as indicated.

\section{RESULTS}

\section{New records for Tanzania}

Brachycorythis ovata Lindl., Gen. Sp. Orch. P1.: 363 (1838). subsp. schweinfurthii (Rchb.f.) Summerh., Kew Bull. 10: 257 (1955).

Brachycorythis schweinfurthii Rchb.f., Otia Bot. Hamburg.: 59 (1878).

Brachycorythis ovata var. schweinfurthii (Rchb.f.) Szlach. \& Olszewski, in Fl. Cameroun 34: 72 (1998).

Brachycorythis grandis Kraenzl., Bot. Jahrb. Syst. 51: 377 (1914).

Brachycorythis ugandensis Schltr., Notizbl. Bot. Gart. Berlin-Dahlem 8: 223 (1922).

Brachycorythis grandis var. ugandensis (Schltr.) Braid, Bull. Misc. Inform. Kew 1925: 359 (1925).

Brachycorythis grandis var. sudanensis Braid, Bull. Misc. Inform. Kew 1925: 359 (1925).

Brachycorythis schweinfurthii var. nigerica Braid, Bull. Misc. Inform. Kew 1925: 359 (1925).

Currently known distribution: West Tropical Africa to Kenya

22 IVO NGA SEN 23 CAF CMN CON ZAI 24 ETH SUD 25 KEN TAN? UGA

Summerhayes $(1955,1968)$ does not mention this subspecies as occuring in Tanzania. Piers (1968) states "no records of the plant exists from Tanganyika". Geerinck (1984) and la Croix et al. (1991) also do not mention this taxon for Tanzania. However, Cribb \& Thomas (1997) and la Croix \& Cribb (1995) list the species as occurring in Tanzania, but do not substantiate this with the citation of a specimen. World Checklist of Monocots (2004) list the occurrence in Tanzania as doubtful. Here we confirm the occurrence of this taxon in Tanzania, which becomes its southernmost distribution.

Bytebier B 2544 with Sakwa J; 19 Feb 2003

Njombe (T7), Iringa Region, Njombe District, The Dam, a few hundred meters before the Tanwat office on opposite side of the road

$9^{\circ} 16.82^{\prime} \mathrm{S} 34^{\circ} 46.40^{\prime} \mathrm{E}, 1880 \mathrm{~m}$

At the edge of a small lake in grass

Flowers mauve, petals white

Dups: EA, DSM

Habenaria arianae Geerinck, Notes Taxon. Orchid. Afr. Centr., 5 (Habenaria): 7 (1977). Habenaria williamsonii P.J.Cribb, Kew Bull. 32(1): 143 (1977).

Habenaria sp., Williamson, Orchids S. Centr. Africa: 63 (1977).

Currently known distribution: Burundi, Democratic Republic of Congo and Malawi

23 BUR ZAI 26 MLW 
Geerinck (1980, 1984) and la Croix et al. (1991) list the distribution as limited to Burundi, Zaire and Malawi. La Croix \& Cribb (1995), followed by World Checklist of Monocots (2004), extend this to Angola and Tanzania, but do not cite any specimens to substantiate this extended distribution. After consulting the first author (I. la Croix, pers. com.) we believe this might have been an error, as no specimens for Tanzania or Angola are present at Kew (P.J. Cribb, pers. comm.), the Natural History Museum (BM) or the East African Herbarium (EA). However, here we report that this species does occur in Tanzania, but the record for Angola is unsubstantiated.

Bytebier B 2543 with Sakwa J, 18 Feb 2003

Njombe (T7), Iringa Region, Njombe District, Tanwat plantation near The Rock

$9^{\circ} 17.29^{\prime} \mathrm{S} 34^{\circ} 44.01^{\prime} \mathrm{E}, 1941 \mathrm{~m}$

Very disturbed grassland with a rock outcrop

In pockets of soil on wet rocks

Flowers green, sweetly scented

Dups: EA, BR (spirit only)

Habenaria disparilis Summerh., Kew Bull. 16: 277 (1962).

Currently known distribution: Zaire to South Tropical Africa

23 ZAI 26 MLW ZAM ZIM

Bytebier B 2497 with Sakwa J; 10 Feb 2003

Kibena (T7), Iringa Region, Mufindi District, between Ifunda and Mafinga on Mbeya-Iringa road

$8^{\circ} 07.83^{\prime} \mathrm{S} 35^{\circ} 24.77^{\prime} \mathrm{E}, 1665 \mathrm{~m}$

Moist grassland near roadside

Flowers green

Only one plant seen

Dups: EA, BR (spirit only)

\section{New records for floral region T7}

Brachycorythis congoensis Kraenzl., Orch. Gen. Sp.: 544 (1898).

Brachycorythis hirschbergii Braid, Bull. Misc. Inform. Kew 1925: 358 (1925).

Currently known distribution: Tanzania to Zimbabwe

23 BUR ZAI 25 TAN 26 MLW ZAM ZIM

Tanzania: T4, T8

Bytebier B 2181 with Sakwa J, Davenport T; 7 Jan 2003

Matamba Plateau (T7), Iringa Region, Makete District, track from Chimala towards Matamba, before river bridge near Matamba

$8^{\circ} 54.30^{\prime} \mathrm{S} 33^{\circ} 48.07^{\prime} \mathrm{E} ; 2070 \mathrm{~m}$

Burnt grassland, heavy clay soil

Flowers deep purple, whitish on the inside

Dups: EA, BR (spirit only) 


\section{Interesting record}

Disa erubescens Rendle, J. Bot. 33: 297 (1895).

Disa erubescens var. leucantha Schltr., Bot. Jahrb. Syst. 53: 537 (1915).

Currently known distribution: Tropical Africa

22 NGA 23 BUR CMN RWA ZAI 24 SUD 25 KEN TAN UGA 26 ANG MLW MOZ ZAM ZIM

The flowers for this widespread species are usually recorded as ranging from orange to vermillion or bright red. In wet to swampy grassland along the Mtitu River, South of Kilolo Village, we found a sizeable population of more than a 100 plants of which an estimated $80 \%$ of the plants had normal bright red flowers, while the remaining $20 \%$ of the plants had pure yellow flowers. These figures are highly suggestive of a recessive Mendelian inheritance of the yellow colour. There are no published reports of such a yellow colour form in this species. although collectors have reported it once in herbarium specimen label data (Tawakali, Patel \& Mussa 731, Zomba Plateau, Malawi; dups in MAL, MO). If this was a liberal interpretation of the orange flower colour (the upper petal lobe and the conspicuous anthers are yellow) or if these plants were truly yellow is not known and during many years of orchid observations in Malawi, I.F. la Croix (pers. com.) has never come across any such pure yellow plants.

The yellow flower colour has, however, been recorded in Disa uniflora Berg., an endemic species of the Western Cape of South Africa. In this case, it was shown that yellow mutants are unable to synthesize red anthocyanin pigments in the epidermal cells, thereby revealing the rich yellow carotinoid pigments of the mesophyll cells sandwiched between the epidermal cells (Vogelpoel, 1995). We suspect the same might be happening in this $D$. erubescens mutant although this needs further investigation.

Bytebier B 2512, with Sakwa J; 11 Feb 2003

Kilolo (T7), Iringa Region, Iringa Rural [now Kilolo] District, Lusinga Road from Iringa to Dabaga, just past Kilolo, between river and road

$8^{\circ} 02.27^{\prime} \mathrm{S} 35^{\circ} 51.24^{\prime} \mathrm{E}$; alt. $1782 \mathrm{~m}$

Swampy grassland

Flowers orange-red or pure yellow with red spots inside the dorsal sepal

Extensive population

Dups: EA, DSM, BR, NY

\section{ACKNOWLEDGEMENTS}

Collection of material was authorised by the Tanzania Commission for Science and Technology (COSTECH) under research permit N0.2003-039-NA-2002-117 to B. Bytebier. Financial support was provided by the Foundation for the Furtherance of Scientific Research in Africa (Belgium), Leopold III Foundation (Belgium) and the New York Botanic Garden (USA). The authors wish to thank Dr. Kanyeka and Mr. Mbago of the Botany Department, University of Dar-es-Salaam, and Dr. Davenport of the Southern Highlands Conservation Programme for assistance. 


\section{REFERENCES}

Cribb, P.J. \& G.P. Leedal (1982). The Mountain Flowers of Southern Tanzania. A.A. Balkema, Rotterdam.

Cribb, P.J. \& S. Thomas (1997). 200 Orchidaceae. In S. Edwards, S. Demissew \& I. Hedberg (eds.). Flora of Ethiopia and Eritrea Volume 6. The National Herbarium. Addis Ababa.

Davenport, R.B. \& B. Bytebier (2004). Kitulo Plateau, Tanzania-A first African park for orchids. Orchid Review 112: 161-165.

Geerinck, D. (1980). Notes taxonomiques sur les Orchidacées d'Afrique Centrale. Bulletin du Jardin Botanique National de Belgique 50: 117-122.

Geerinck, D. (1984). Flore d'Afrique Centrale (Zaire-Rwanda-Burundi). Orchidaceae (premiere partie). Jardin Botanique National de Belgique, Meise.

Hollis S. \& R.K. Brummitt (1992). World Geographical Scheme for Recording Plant Distributions. International Working Group on Taxonomic Databases for Plant Sciences, Pittsburgh.

la Croix I.F. \& P.J. Cribb. (1995). 163. Orchidaceae. In G.V. Pope (ed.) Flora Zambesiaca Vol 11 Part 1. Flora Zambesiaca Management Committee, London.

la Croix, I.F., E.A.S. la Croix \& T.M. la Croix (1991). Orchids of Malawi. A.A.Balkema, Rotterdam.

Linder, H.P \& H. Kurzweil (1999). Orchids of Southern Africa. A.A. Balkema, Rotterdam.

Lovett, J.C, R.E. Gereau \& K.J. Sidwell (1994). Vegetation and phytogeography of the Kitulo Plateau, Southern Tanzania. Proceedings of the XIII ${ }^{\text {th }}$ Plenary Meeting AETFAT, Malawi, 2:1025-1041.

Piers, F. (1968). Orchids of East Africa. J. Cramer, Lehre, Germany.

Summerhayes, V.S. (1955). A revision of the genus Brachycorythis. Kew Bulletin 10: 221-264.

Summerhayes, V.S. (1968). Orchidaceae (Part I). In E. Milne-Redhead \& R.M. Polhill (eds.) Flora of Tropical East Africa. Crown Agents for Oversea Agents and Governments, London.

Vogelpoel, L. (1995). Green, yellow, white and black colours in orchid flowers. Part 2some observations on pigments of plastid origin-Continued. South African Orchid Journal 26(3): 87-90.

World Checklist of Monocots (2004). The Board of Trustees of the Royal Botanic Gardens, Kew. Published on the Internet; http://www.kew.org/monocotChecklist/ [accessed 01 August 2004] 